\title{
TU/e EnмHONEN

\section{The systematic error in photometric set-point titrations of submicromolar amounts of calcium and zinc}

\section{Citation for published version (APA):}

Smit, W., \& Stein, H. N. (1976). The systematic error in photometric set-point titrations of submicromolar amounts of calcium and zinc. Analytica Chimica Acta, 83(1), 297-307. https://doi.org/10.1016/S00032670(01)84656-0

DOI:

10.1016/S0003-2670(01)84656-0

Document status and date:

Published: 01/01/1976

\section{Document Version:}

Publisher's PDF, also known as Version of Record (includes final page, issue and volume numbers)

\section{Please check the document version of this publication:}

- A submitted manuscript is the version of the article upon submission and before peer-review. There can be important differences between the submitted version and the official published version of record. People interested in the research are advised to contact the author for the final version of the publication, or visit the $\mathrm{DOI}$ to the publisher's website.

- The final author version and the galley proof are versions of the publication after peer review.

- The final published version features the final layout of the paper including the volume, issue and page numbers.

Link to publication

\section{General rights}

Copyright and moral rights for the publications made accessible in the public portal are retained by the authors and/or other copyright owners and it is a condition of accessing publications that users recognise and abide by the legal requirements associated with these rights.

- Users may download and print one copy of any publication from the public portal for the purpose of private study or research.

- You may not further distribute the material or use it for any profit-making activity or commercial gain

- You may freely distribute the URL identifying the publication in the public portal.

If the publication is distributed under the terms of Article 25fa of the Dutch Copyright Act, indicated by the "Taverne" license above, please follow below link for the End User Agreement:

www.tue.nl/taverne

Take down policy

If you believe that this document breaches copyright please contact us at:

openaccess@tue.nl

providing details and we will investigate your claim. 
Analytica Chimica Acta, 83 (1976) 297-307

(CElsevier Scientific Publishing Company, Amsterdam - Printed in The Netherlands

\section{THE SYSTEMATIC ERROR IN PHOTOMETRIC SET-POINT TITRATIONS OF SUBMICROMOLAR AMOUNTS OF CALCIUM AND ZINC}

W. SMIT and H. N. STEIN

Laboratory of General Chemistry, Eindhoven University of Technology, Eindhoven (The Netherlands)

(Received 3rd November 1975)

\section{SUMMARY}

Although reproducible results can be obtained in photometric set-point titrations of submicromolar amounts $\left(5 \cdot 10^{-5} \mathrm{M}\right.$ and higher) of calcium(II) and zinc(II) by using an automatic titrator, the systematic error can be considerable. This error is partly intrinsic in nature, but there is an additional error caused by dilution in successive titrations. Accurate values can be obtained only when standardization and actual titrations are performed under the same conditions of dilution, set-point, indicator concentrations, etc.

To investigate the adsorption of $\mathrm{Ca}^{2+}$ and $\mathrm{Zn}^{2+}$ ions on solids from solutions of calcium and zinc salts in dimethyl sulfoxide in the concentration range $5 \cdot 10^{-5} \mathrm{M}$ and higher, a method of determining small concentration changes accurately in less than $1 \mathrm{ml}$ of the liquid concerned was required. A method with a rapid automatic titrator, reported by Slanina et al. [1] seemed to be suitable; a sample (e.g. $100 \mu \mathrm{l}$ ) is added to a solution in a titration cell in a photometer and the titrator adds the complexing agent, up to a pre-adjusted absorbance value, within $30 \mathrm{~s}$. After the burette has been read, a new sample is added. The titrator adds the complexing agent until the set-point is reached again. The number of times this procedure can be repeated in the same titration solution depends, among other factors, on the degree of dilution caused by each titration.

In comparison with the procedure in which the complete plot of absorbance vs. volume of titrant curve is measured, followed by an end-point determination by means of a tangent procedure [2], the method of 'Slanina et al [1] has the following advantages: (i) it needs less time, (ii) the statistical contribution to the total error can be reduced by carrying out many titrations in succession in one titration solution, (iii) the blank determination can be omitted because it is included when the set-point is reached for the first time.

The absence of systematic errors, which might be concluded from the results of Slanina et al. cannot be confirmed, however. The essence of the method is that, after each sample injection, the titration is continued until a fixed absorbance value has been reached. If the absorbance/ (ratio of titrant to titrand) relationship is dependent on the ratio of the total indicator and metal 
concentrations [3], it appears that a systematic error may result merely from the change of this ratio after each of the successive titrations. This paper deals with the systematic errors involved.

\section{THEORY}

The following treatment of the theoretical titration curves extends that reported by Kragten [2]. The terminology and symbols follow present practice $[4,5]$, and $C_{\mathrm{M}}=$ total concentration of metal $\mathrm{M}$ present in any form;

$C_{\mathrm{L}}=$ total concentration of ligand $\mathrm{L}$ present in any form;

$C_{\mathrm{I}}=$ total concentration of indicator I present in any form;

$f=C_{\mathrm{L}} / C_{\mathrm{M}}=$ titration parameter;

$\beta=C_{\mathrm{I}} / C_{\mathrm{M}}=$ relative amount of indicator;

$m i=[\mathrm{MI}] / C_{1}=$ fraction of indicator bound to the metal.

It is assumed that only 1:1 complexes are formed between $\mathrm{M}$ and $\mathrm{I}$.

As discussed by Freese [6] and Kragten [2], the dimensionless quantities $Z$ are introduced instead of the conditional stability constants.

$Z_{\mathrm{I}}=C_{\mathrm{I}} K_{\mathrm{MI}^{\prime} \mathrm{I}^{\prime}(\mathrm{MII})^{\prime}}$

$Z_{\mathrm{MI}}=C_{\mathrm{MI}^{\prime}} K_{\mathrm{MI}^{\prime} \mathrm{L}^{\prime}(\mathrm{ML})^{\prime}}$

in which the $K$ values are conditional stability constants defined by

$K_{\mathrm{MI}^{\prime} \mathrm{I}^{\prime}(\mathrm{MII})}=\left[\mathrm{MI}^{\prime}\right] /\left[\mathrm{M}^{\prime}\right]\left[\mathrm{I}^{\prime}\right]$

$K_{\mathrm{MI}^{\prime} \mathrm{L}^{\prime}(\mathrm{ML})^{\prime}}=\left[\mathrm{ML}^{\prime}\right] /\left[\mathrm{M}^{\prime}\right]\left[\mathrm{L}^{\prime}\right]$

(constant ionic strength, and constant concentrations of species which can form complexes with either $\mathrm{M}, \mathrm{L}$ or I are assumed).

In the conditional stability constants all side-reactions (e.g. association complexes of ligand ions with $\mathrm{H}^{+}$ions) are taken into account. For convenience the primes will be omitted.

The following mass balances hold

$C_{\mathrm{I}}=[\mathrm{I}]+[\mathrm{MI}]$

$C_{\mathrm{MI}}=[\mathrm{M}]+[\mathrm{MI}]+[\mathrm{ML}]$

$C_{\mathrm{L}}=[\mathrm{L}]+[\mathrm{ML}]=f C_{\mathrm{MI}}$

By eliminating $[M],[L]$, etc., from these equations, the titration parameter $f$ is found as a function of the dimensionless quantities $m i, \beta, Z_{\mathrm{I}}$ and $Z_{\mathrm{M}}$

$f=1-\beta m i-\frac{\beta m i}{Z_{\mathrm{I}}(1-m i)}+\frac{1}{\beta m i} \frac{Z_{\mathrm{I}}}{Z_{\mathrm{M}}}-\frac{1}{\beta} \frac{Z_{\mathrm{I}}}{Z_{\mathrm{M}}}-(1-m i) \frac{Z_{\mathrm{I}}}{Z_{\mathrm{M}}}-\frac{1}{Z_{\mathrm{M}}}$ 
If the photometer is set to measure the absorption of the metal-indicator complex MI, the absorbance is a linear function of $m i(A=a+b m i)$. If the instrument is set to measure the absorbance of the free indicator, $I$, the absorbance will be a linear function of $i=[\mathrm{I}] / C_{1}$, i.e. the fraction of the total amount of indicator present not bound to a metal ion $(A=a,+b, i)$. The titration parameter $f$ as a function of $i, \beta, Z_{\mathrm{I}}$ and $Z_{\mathrm{M}}$ is given by

$f=1-\beta(1-i)-\frac{\beta(1-i)}{Z_{\mathrm{I}} i}+\frac{1}{\beta(1-i)} \frac{Z_{1}}{Z_{\mathrm{M}}}-\frac{1}{\beta} \frac{Z_{\mathrm{x}}}{Z_{\mathrm{M}}}-i \frac{Z_{\mathrm{I}}}{Z_{\mathrm{M}}}-\frac{1}{Z_{\mathrm{M}}}$

In Fig. 1 some theoretical titration curves are drawn with $Z_{\mathrm{I}}=10, Z_{\mathrm{MI}}=10^{4}$ and with some $\beta$-values. The curves $m i(f)$ and $i(f)$ with the same $\beta$-value are the mirror image of each other with respect to the line $m i=i=0.5$.

Some calculated examples will be used to examine whether systematic errors occur when each of the successive titrations is finished at the same final absorbance value, determined by $m i_{f}$ or $i_{f}$. These calculations assume that there are no changes in volume, in the conditional stability constants, or in the activity coefficients. The systematic error occurring under these conditions is denoted as the intrinsic systematic error.

Suppose that the photometer is set to measure the absorption of MI ("MI titration") and that $C_{1}=5 \cdot 10^{-6} \mathrm{M}$. By adding an auxiliary solution containing $\mathrm{M}$ ions, $C_{\mathrm{M}}$ is brought to the value $C_{\mathrm{MI}}{ }^{\circ}=10 \cdot 10^{-6} \mathrm{M}$, thus $\beta^{\circ}=0.5$. Then the complexing agent is added up to a chosen $m i_{f}$ value, after which a sample is added increasing $C_{\mathrm{M}}$ by $5 \cdot 10^{-6} \mathrm{M}$. After this addition $\beta=0.3333$ and $Z_{\mathrm{M}}=$ $1.5 Z_{\mathrm{MI}}^{\circ}$. With the accompanying values of $Z_{\mathrm{MI}}^{\circ}, Z_{\mathrm{I}}$ and $m i_{f}, f$ can be found, then $C_{\mathrm{L}}$ follows from $C_{\mathrm{L}}=f C_{\mathrm{M}}$. The calculation is repeated for successive equal sample additions. The differences between the successive $C_{\mathrm{L}}$ values correspond to the amounts of cation titrated.

Table 1 gives the results of the calculations with $m i_{f}=0.3, Z_{\mathrm{M}}^{\circ}=10^{4}$ and $Z_{\mathrm{I}}=10$. The same results are obtained if the photometer is set to measure the absorbance of I ("I titration") and the titrations are finished at $i_{r}=0.7$. The last column confirms the reproducibility of the titrations and demonstrates

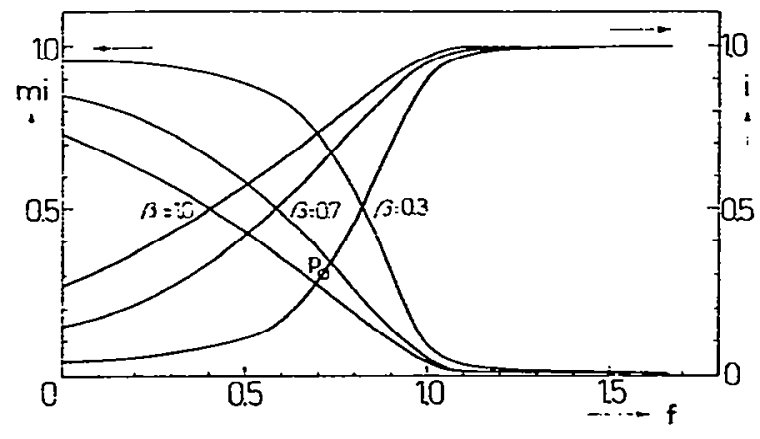

Fig. 1. Theoretical titration curves constructed with $Z_{\mathrm{I}}=10, Z_{\mathrm{M}}=10^{4}$ and with $\beta=C_{\mathrm{I}} / C_{\mathrm{M}}$ $=0.3,0.7$ and 1.0. 
TABLE 1

Calculation of the amount of cation titrated theoretically in a series of titrations

\begin{tabular}{llllcl}
\hline$C_{\mathrm{M}}\left(\cdot 10^{-6}\right)$ & $\beta$ & $Z_{\mathrm{M}} / Z_{\mathrm{M}}{ }^{\circ}$ & $f$ & $f \cdot C_{\mathrm{M}}\left(\cdot 10^{-6}\right)$ & $\Delta\left(\cdot 10^{-6}\right)$ \\
\hline 10 & 0.5000 & 1.0 & 0.8324 & 8.3244 & \\
15 & 0.3333 & 1.5 & 0.8899 & $\mathbf{1 3 . 3 4 7 9}$ & $\mathbf{5 . 0 2 3 5}$ \\
20 & 0.2500 & 2.0 & 0.9186 & 18.3710 & $\mathbf{5 . 0 2 3 1}$ \\
25 & 0.2000 & 2.5 & 0.9358 & $\mathbf{2 3 . 3 9 4 4}$ & $\mathbf{5 . 0 2 3 4}$ \\
30 & 0.1667 & 3.0 & 0.9472 & 28.4173 & 5.0229 \\
35 & 0.1429 & 3.5 & 0.9555 & $\mathbf{3 3 . 4 4 0 5}$ & $\mathbf{5 . 0 2 3 2}$ \\
40 & 0.1250 & 4.0 & $\mathbf{0 . 9 6 1 6}$ & $\mathbf{3 8 . 4 6 4 4}$ & $\mathbf{5 . 0 2 3 9}$ \\
\hline
\end{tabular}

$C_{\mathrm{I}}=5 \cdot 10^{-6} \mathrm{M}, Z_{\mathrm{M}}^{\circ}=10^{4}, Z_{\mathrm{I}}=10, m i_{f}=0.3, \Delta C_{\mathrm{MI}}=5 \cdot 10^{-6} \mathrm{M}$.

moreover that an intrinsic systematic error can occur. This error depends on $Z_{\mathrm{M}}{ }^{\circ} / Z_{\mathrm{I}}$ and on $m i_{f}$ (or $i_{f}$ ), as follows from Table 2 , which shows the results of the calculations for the system considered in the calculations of Table 1. With any of these combinations of $Z_{\mathrm{M}}{ }^{\circ}, Z_{\mathrm{I}}$ and $i_{f}$ (or $m i_{f}$ ), the $\Delta$ values between successive titrations are constant to the same degree as the values in Table 1. From Table 2 it follows that the value of $Z_{1}$ has a slight influence only on the intrinsic systematic error at equal $Z_{M}{ }^{\circ} / Z_{1}$ ratios. The statistical error will decrease as $\mathrm{d} f / \mathrm{d} i$ (or $\mathrm{d} f / \mathrm{d} m i$ ) at the set-point decreases.

Differentiation of eqns. (8) and (9) gives

$\left(\frac{\mathrm{d} f}{\mathrm{~d} i}\right)_{i_{f}}=\beta+\frac{\beta}{Z_{\mathrm{I}_{f}}{ }^{2}}+\left(\frac{1}{\beta\left(1-i_{f}\right)^{2}}-1\right) \frac{Z_{\mathrm{I}}}{Z_{\mathrm{M}}}$

$-\left(\frac{\partial f}{\partial m i}\right)_{m i_{f}}=\beta+\frac{\beta}{Z_{1}\left(1-m i_{f}\right)^{2}}+\left(\frac{1}{\beta m i_{f}^{2}}-1\right) \frac{Z_{I}}{Z_{M}}$

If titrations with $Z_{\mathrm{MI}} / Z_{\mathrm{I}}=5 \cdot 10^{2}$ or higher, but with different $Z_{\mathrm{I}}$ values are compared, it can be deduced from these equations that the statistical contribution to the error increases strongly with decreasing $Z_{\mathrm{I}}$ as soon as $Z_{\mathrm{I}}$ becomes less than about 10 . Moreover, it follows that $i_{f}$ should not be chosen

TABLE 2

Dependence of the amount of cation titrated theorctically on $Z_{M}^{\circ}, Z_{\mathrm{I}}$ and $i_{f}$ or $i m_{f}$

\begin{tabular}{lrlll}
\hline$Z_{\mathrm{M}}{ }^{\circ}$ & \multicolumn{2}{l}{$Z_{\mathrm{I}}$} & $\Delta\left(\cdot 10^{-0}\right)$ & \\
\cline { 3 - 5 } & & $i_{f}=0.3 ; m i_{f}=0.7$ & $i_{f}=0.5 ; m i_{f}=0.5$ & $i_{f}=0.7 ; m i_{f}=0.3$ \\
\hline $10^{4}$ & 10 & 5.004 & 5.010 & 5.023 \\
$10^{5}$ & 10 & 5.0004 & 5.001 & 5.002 \\
$10^{5}$ & 70 & 5.003 & 5.007 & 5.016 \\
$10^{5}$ & 100 & 5.004 & 5.010 & 5.023 \\
$10^{3}$ & 1 & - & 5.010 & 5.023 \\
\hline
\end{tabular}


close to 0 nor $m i_{f}$ close to 1 , as might be the tendency from Table 2 in order to make the intrinsic systematic error negligible when $Z_{\mathrm{M}} / Z_{\mathrm{I}} \leqslant 10^{3}$.

From these remarks, and from Table 2 it follows that the titration conditions, $\log Z_{M} / Z_{1}>3.5$ and $\log Z_{1}>1$, deduced by Kragten [2] in order to maintain the total error in the tangent procedure below $1 \%$, hold for the present method, and his procedure, which permits the selection of a suitable titration medium, can also be of use here. The systematic error arising from dilution caused by the addition of the sample and the titrant will be treated in the discussion section.

\section{EXPERIMENTAL}

\section{Apparatus}

A Zeiss spectrophotometer PMQ II, with built-in magnetic stirrer, was used. The dimensions of the titration cell were $2.000 \times 2 \times 4 \mathrm{~cm}$. The titrant was delivered from a Metrohm E457 0.5-ml micro-burette, coupled to an automatic titrator as described by Slanina et al. [1]. The microburette was driven by a stepping motor; to minimize the influence of imperfections in the mechanical coupling between the stepping motor and the microburette, causing troubles at the set-point, the titrator was adjusted to let the burette deliver the titrant very slowly at the absorbance value corresponding to the end-point: the precision, especially when the relationship between absorbance and volume of titrant was less steep, was greatly improved. The use of the automatic titrator is convenient but not essential for the method. The samples and indicator solution were added with Gilson Pipetman P200 micropipettes (adjustable), and Brand Microliter pipettes (fixed values).

\section{Reagents}

Calcium titrations. The medium was $0.5 \mathrm{M}$ KOH containing $0.5 \mathrm{~g} \mathrm{KCN}$ per $100 \mathrm{ml}$. The indicator was $1.2 \cdot 10^{-3} \mathrm{M}$ calcein (Fluka) in dimethylsulfoxide (this solution is fairly stable). The calcium solution was $0.001783 \mathrm{M} \mathrm{CaCl}_{2}$, obtained by dilution of Merck 9876 Titrisol calcium standard solution, and the titrant was $10^{-3} \mathrm{M}$ EGT $A$ in dilute ammonia, obtained by a ten-fold dilution of $10^{-2} \mathrm{M}$ EGTA solution standardized with $0.01783 \mathrm{M} \mathrm{CaCl}_{2}$ solution on a macro scale. This gave $0.00973 \mathrm{M}$ with calcein as indicator $[7,8]$ and $0.00966 \mathrm{M}$ with Merck buffer indicator tablets. The strength of the $10^{-3} \mathrm{M}$ EGTA solution was taken as $0.970 \cdot 10^{-3} \mathrm{M}$.

Zinc titrations. The medium was $0.2 \mathrm{M}$ sodium acetate-acetic acid buffer $\mathrm{pH}$ 6. Xylenol orange, $2 \cdot 10^{-4} \mathrm{M}$ in water, served as indicator. Zinc solution $\left(10^{-3} \mathrm{M} \mathrm{ZnCl}_{2}\right)$ was titrated with $10^{-3} \mathrm{M}$ EDTA, standardized with the ainc solution on a macro scale with xylenol orange as indicator in hexamethylenetetramine buffer. The concentration was $0.991 \cdot 10^{-3} \mathrm{M}$. 
Procedure

Only some general directions are given for the amounts of indicator, set-point, etc., which depend on the circumstances. For instance, when very small quantities $\left(<10^{-4} \mathrm{M}\right)$ of calcium ions were titrated more reproducible results were obtained on addition of a smaller amount of indicator, although the absorbance changed in that case by less than 0.1 unit when a complete titration curve was measured.

I Titrations. Set the spectrophotometer to measure the absorbance of free indicator (calcein at $510 \mathrm{~nm}$; xylenol orange at $427 \mathrm{~nm}$ ). To the titration solution $(8 \mathrm{ml})$ add indicator solution to make the absorbance $A$ change by more than 0.1 unit in a complete titration curve. Add sufficient complexing agent to bring the indicator completely into its free form. Adjust the light intensity or amplification until the meter indicates, for example, 0.3 absorbance units. Add metal ions from an auxiliary solution to make $\beta \leq 0.5$. Select a set-point on the lower side of the approximately linear part of the rising section of the titration curve (e.g. point $P$ in Fig. 1). Bring the absorbance to this value by adding the complexing agent. Inject the sample (microliter pipette) and titrate until the set-point is reached again. Read the burette, add a new sample, etc.

$M I$ Titrations. Set the spectrophotometer to measure the absorption of the metal-indicator complex $\left(\mathrm{Ca}^{2+}\right.$ at $486 \mathrm{~nm}, \mathrm{Zn}^{2+}$ at $570 \mathrm{~nm}$ ). Add indicator solution to the titration solution $(8 \mathrm{ml})$ to make the absorbance change in a complete titration curve over more than 0.1 unit. Add $\mathrm{M}^{2+}$ ions from an auxiliary solution to make $\beta \leqslant 0.50$. Adjust the light intensity or amplification until the meter indicates, for example, 0.3 absorbance units. Select the set-point on the descending part of the titration curve. Add the complexing agent until this value is reached. Inject the sample and titrate until the set-point is reached again. Read the burette, add a new sample, etc.

Writing down the absorbance value after each sample injection may help to detect irregularities caused by excessive titrant addition, injection errors, etc. The number of possible titrations which can be performed in one titration solution depends on the circumstances and must be judged from the decreasing reproducibility with increasing number of titrations, e.g., it will be smaller when the liquid volume added per titration is relatively large.

RESULTS

Titration curves for the calcium titrations are shown in Fig. 2. For curve (b), EGT A solution was added to convert the indicator completely to its calcein form before titration with $0.0018 \mathrm{M} \mathrm{CaCl}_{2}$. In curve (c), only $10 \mu \mathrm{l}$ of indicator solution was used (this gives the same indicator concentration as in the titration solution of Slanina et al. [1]). 


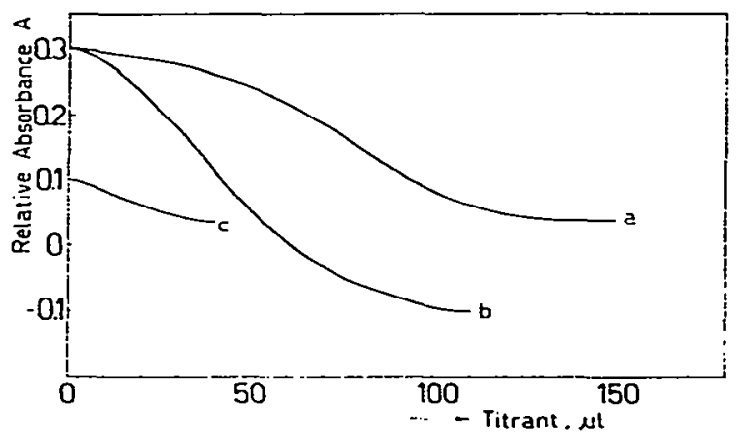

\begin{tabular}{|c|c|c|c|c|c|}
\hline & Method & $\lambda(\mathrm{nm})$ & Titrand & $\begin{array}{l}\text { Indicator } \\
(\mu I)\end{array}$ & Titrant \\
\hline Curve a & MI & 486 & $100 \mu 10.00178 \mathrm{M} \mathrm{Ca}^{2 *}$ & 50 & 0.0019 M EGTA \\
\hline Curve b & I & 510 & EGTA & 50 & $0.0018 \mathrm{M} \mathrm{CaCl}_{2}$ \\
\hline Curve c & MII & 486 & $100 \mu l 0.00178 \mathrm{M} \mathrm{Ca}^{2+}$ & 10 & EGTA \\
\hline
\end{tabular}

Fig. 2. Titration curves in Ca-EGTA titrations with calcein.

Titration curves for the zinc titrations are shown in Fig. 3. Table 3 gives the results of the standardization of the EGTA solution against the $\mathrm{CaCl}_{2}$ standard solution. The value of $A$ was set at 0.300 absorbance units in the MI titrations after the addition of $50 \mu \mathrm{l}$ of indicator solution and $100 \mu \mathrm{l}$ of $\mathrm{CaCl}_{2}$ solution; and in the I titrations after the addition of $50 \mu \mathrm{l}$ of indicator solution and $100 \mu \mathrm{l}$ of $10^{-3} \mathrm{M}$ EGTA. In both cases the set-point was 0.100 .

Table 4 gives the results of the titrations with $\mathrm{ZnCl}_{2}$ solution. In the MI titrations the absorbance was set at 0.300 units after the addition of $50 \mu l$ of indicator solution and $100 \mu \mathrm{l}$ of $10^{-3} \mathrm{M} \mathrm{ZnCl}_{2}$ solution. The set-point was 0.100 absorbance units. In the I titrations the absorbance was set at 0.100 after the addition of $50 \mu \mathrm{l}$ of indicator solution and $50 \mu \mathrm{l}$ of $10^{-3} \mathrm{M}$ EDTA. The set-point of these titrations was 0.040 absorbance units. The standard

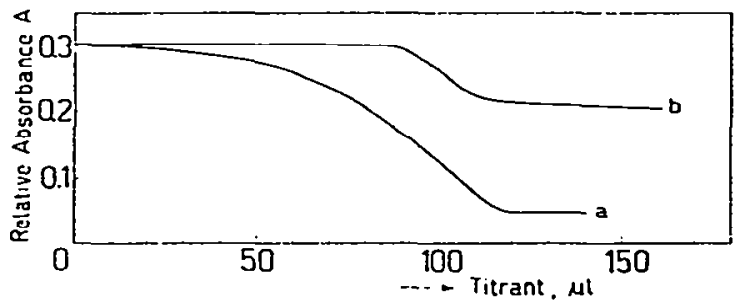

\begin{tabular}{llllll}
\hline & Method & $\lambda(\mathrm{nm})$ & Titrand & $\begin{array}{l}\text { Indicator } \\
(\mu l)\end{array}$ & Titrant \\
\hline Curve a & MI & 570 & $100 \mu l 0.001 \mathrm{M} \mathrm{Zn}^{2+}$ & 50 & $0.001 \mathrm{M} \mathrm{EDTA}$ \\
Curve b & $\mathrm{I}$ & 427 & $100 \mu 10.001 \mathrm{M} \mathrm{EDTA}$ & 50 & $0.001 \mathrm{M} \mathrm{ZnCl}_{2}$ sol.
\end{tabular}

Fig. 3. Titration curves in $\mathrm{Zn-EDTA}$ titration with xylenol orange. 
TABLE 3

Standardization of EGTA with $\mathrm{CaCl}_{2}$ solution

\begin{tabular}{|c|c|c|c|c|c|}
\hline $\begin{array}{l}\mathrm{CaCl}_{2} \\
0.00178 \mathrm{M} \\
(\mu 1)\end{array}$ & $\begin{array}{l}\text { Ca } \\
\text { present } \\
(\mu \mathrm{g})\end{array}$ & $\begin{array}{l}\text { No. of } \\
\text { detns. }\end{array}$ & Method & $\begin{array}{l}\text { EGTA found } \\
\left(\cdot 10^{-3} \mathrm{M}\right)\end{array}$ & $\stackrel{s}{\left(\cdot 10^{-3} \mathrm{M}\right)}$ \\
\hline \multirow[t]{4}{*}{20.11} & 1.43 & 10 & MI & 1.006 & 0.007 \\
\hline & & 13 & MI & 1.000 & 0.005 \\
\hline & & 10 & I & 0.890 & 0.005 \\
\hline & & 11 & I & 0.886 & 0.005 \\
\hline \multirow[t]{4}{*}{39.63} & 2.82 & 6 & MI & 1.004 & 0.004 \\
\hline & & 6 & MI & 1.004 & 0.003 \\
\hline & & 6 & I & 0.902 & 0.004 \\
\hline & & 6 & I & 0.904 & 0.003 \\
\hline \multirow[t]{4}{*}{59.30} & 4.21 & 4 & MI & 1.015 & 0.005 \\
\hline & & 4 & MI & 1.014 & 0.006 \\
\hline & & 4 & I & 0.906 & 0.006 \\
\hline & & 4 & I & 0.907 & 0.004 \\
\hline
\end{tabular}

TABLE 4

Standardization of EDTA with $\mathrm{ZnCl}_{2}$ solution

\begin{tabular}{|c|c|c|c|c|c|}
\hline $\begin{array}{l}\mathrm{ZnCl}_{2} \\
0.00101 \mathrm{M} \\
(\mu \mathrm{l})\end{array}$ & $\begin{array}{l}\mathrm{Zn} \\
\text { present } \\
(\mu \mathrm{g})\end{array}$ & $\begin{array}{l}\text { No. of } \\
\text { detns. }\end{array}$ & Method & $\begin{array}{l}\text { EDTA found } \\
\left(\cdot 10^{-3} \mathrm{M}\right)\end{array}$ & $\stackrel{s}{\left(\cdot 10^{-3} \mathrm{M}\right)}$ \\
\hline \multirow[t]{3}{*}{20.11} & 1.32 & 13 & MI & 0.981 & 0.005 \\
\hline & & 18 & MI. & 0.970 & 0.006 \\
\hline & & 16 & I & 0.977 & 0.007 \\
\hline \multirow[t]{2}{*}{39.57} & 2.60 & 12 & MII & 0.998 & 0.003 \\
\hline & & 12 & I & 0.975 & 0.004 \\
\hline \multirow[t]{2}{*}{59.70} & 3.93 & 8 & MI & 1.008 & 0.003 \\
\hline & & 8 & I & 0.983 & 0.004 \\
\hline
\end{tabular}

deviation of the mean, as shown in Tables 3 and 4 includes the standard deviation of the calibration of the microliter pipette.

\section{DISCUSSION}

Tables 3 and 4 show that the $\mathrm{MI}$ and $\mathrm{I}$ titrations give different results. For the calcium titrations this difference is ca. $10 \%$. The macroscale-titration value lies between the MI and I titration values.

An adaptation of the theoretical curve to experimental curve (a) of Fig. 2 was made, guided by the knowledge that the curvature of the upper part of the $m i$ vs. $f$ curve increases with decreasing $Z_{1}$, and that the transition between the parts of the curve before and after equivalence point $(f=1)$ becomes less abrupt when $Z_{M} / Z_{I}$ decreases (this follows from eqns. (8) and (9)). 
A possible adaptation is $\beta=0.25$ (taken somewhat lower than calculated from the amount of substances present in the solution because of the possible impurity of the calcein), $Z_{\mathrm{I}}=0.5$ and $Z_{\mathrm{M}}=10^{3}$. The volume vs. $f$ and absorbance vs. $m i$ relationships are $V=110 f$ (the equivalence point in Fig. 2, Curve (a), was taken as $110 \mu \mathrm{l}$ ) and $A=0.036+0.421 \mathrm{mi}$ (in this adaptation $A=0.300, f=0$, corresponds to $m i=0.627$ and $A=0.036$ (with excess EGTA) to $m_{i}=0$ ).

The theoretical $m i$ vs. $f$ curves with $\beta=0.25, Z_{M}=10^{3}$ and $Z_{1}=0.5,1$ or 10 are depicted in Fig. 4. The experimental points converted to $\left(m_{i}, f\right)$ are indicated by crosses. According to this adaptation, the set-point $A=0.1$ would correspond to $m i_{f}=0.152$. A calculation, as for that carried out for Table 1, with the experimental data of the MI titration with additions of $20 \mu \mathrm{l}$ of $\mathrm{CaCl}_{2}$ solution, gives an intrinsic systematic error of $+1.0 \%$ in the consumption of EGTA solution.

The absorbance vs. mi relationship for curve (b) of Fig. 2 is $A=-0.34+$ $0.64 i$ ( $A=-0.10$ corresponds approximately to $i=0.373$, the value obtained when $m i=0.627$ is mirrored with respect to the line $m i=0.5$; compare Fig. 1 ). Consequently, at the set-point $A=0.1$ and $i_{f}=0.69$. The intrinsic systematic error of the I titration, with additions of $20 \mu \mathrm{I}$ of $\mathrm{CaCl}_{2}$ solution, is $+0.5 \%$ in the consumption of EGTA solution.

In both cases the intrinsic error would lead to a low result for the concentration of the EGTA solution. Comparison with the macroscale titration value shows that other opposing systematic errors must be present for both titration methods. A possible source is the dilution factor.

The titrations were finished at a fixed absorbance value in a MI titration. Because $C_{1}$ changes, the relation $A=a+b^{\prime}[\mathrm{MI}]$ holds instead of $A=a+b m i$. Substituting $[\mathrm{MI}]=m_{i}, C_{\mathrm{I}}$, with $\triangle A=0$, gives

$\left(\frac{\Delta m_{i}}{m_{i}}\right)_{f}=-\frac{\Delta C_{\mathrm{I}}}{C_{\mathrm{I}}}$

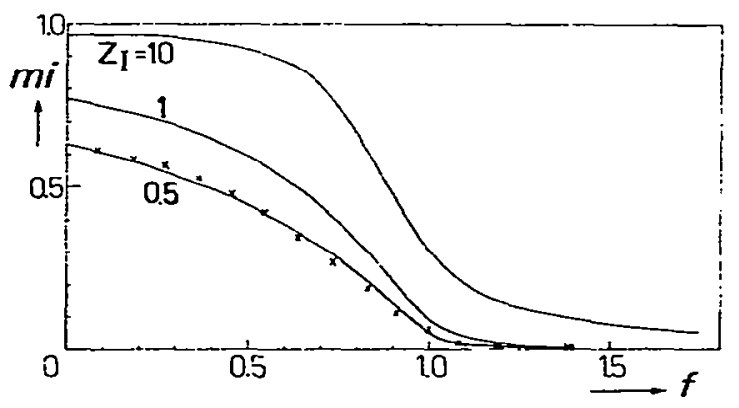

Fig. 4. Adaptation of the theoretical curve to the measured points in the Ca-EGTA titration a of Fig. 2. Theoretical curves with $\beta=0.25, Z_{\mathrm{MI}}=10^{3}$, and $Z_{\mathrm{I}}=0.5,1$ and 10 . The volume vs. $f$ and absorbance vs. $m i$ relationships are $V=110 f$ and $A=0.036+0.421 \mathrm{mi}$. 
For titrations with the addition of $20 \mu \mathrm{l}$ of $\mathrm{CaCl}_{2}$ solution the change in volume per titration is $60 \mu \mathrm{l}$, thus $\left(\Delta m_{i} / m i\right)_{f}=0.0075$. Taking this change in $m i_{f}$, and those of $Z_{M}$ and $Z_{\mathrm{I}}$ because of the dilution, into account a theoretical error of $-0.2 \%$ in the consumption of EGTA solution for the MI titration can be calculated.

For the I titration $(\Delta i / i)_{f}=-\Delta C_{\mathrm{I}} / C_{\mathrm{I}}=0.0075$, the theoretical systematic error in the consumption of EGTA solution is $+3.8 \%$. With the macroscale titration value as reference, values of $0.933 \cdot 10^{-3} \mathrm{M}$ for the I titration and $0.972 \cdot 10^{-3} \mathrm{M}$ for the MI titration should be found for the EGTA solution. These values still differ by 3-4\% from the experimental values, indicating other sources of errors, which may have their origin in changes of the activity coefficients and in factors such as $\alpha_{\mathrm{MI}(x)}=\left[\mathrm{MI}^{\prime}\right] /[\mathrm{MI}]$ in successive titrations. I $i$ should further be noted that $m i$ and $i$ used in the theory refer to [MI'] and [I'] although the absorption is determined by [MI] and [I] , respectively.

With the zinc titrations, the difference between the results of the two methods and the difference between the macroscale titration value are smaller. The abrupt change in the slope of the titration curves of Fig. 3 near the equivalence point and the slope near the beginning of the titration curve $3(\mathrm{a})$, suggest that $Z_{\mathrm{M}} / Z_{1}>10^{4}$ and $Z_{1}>1$. The intrinsic error is therefore smaller; because the $m i(f)$ and $i(f)$ curves are steeper, the errors caused by dilution are also smaller.

It is concluded that the titration method of Slanina et al. [1] allows reproducible results to be obtained both in a series in one titration solution and when the titration series is repeated in a fresh titration solution. The systematic error, however, can be considerable. The magnitude of this error depends on the ratio $Z_{\mathrm{M}} / Z_{\mathrm{I}}$, on $Z_{\mathrm{I}}$, on the position of the set-point on the absorbance vs. (volume of titrant) curve, and on the dilution caused by each single titration. On account of the possibly large systematic error, accurate cation concentration values cannot be expected when the titrant concentration found from a macroscale titration is used.

The systematic error can be eliminated by standardizing the titrant with a standard metal salt solution under the same conditions of dilution, set-point, indicator concentration, etc., as in the actual titration. The condition of equal dilution can easily be fulfilled by coinjection of a volume of water or solvent such that

$$
V_{\text {sample }}^{\prime}+\mathrm{V}_{\text {titrant }}=V_{\text {sample }}+V_{\text {titrant }}+V_{\text {solvent }}
$$

where the left-hand side terms refer to the standardization experiment.

The method can be used to determine small concentration differences between two solutions, as in adsorption experiments, and with other cations if a suitable titration medium is selected [2]. 


\section{REFERENCES}

1 J. Slanina, P. Vermeer, G. Mook, H. F. R. Reinders and J. Agterdenbos, Z. Anal. Chem., 260 (1972) 354.

2 J. Kragten, Taianta, 18 (1971) 311.

3 J. B. Headridge, Photometric Titrations, Pergamon, Oxford, 1961.

4 A. Ringbom, Complexation in Analy tical Chemistry, Interscience, New York, 1963.

5 G. Schwarzenbach and H. Flaschka, Die komplexometrische Titration, Ferdinand Enke Verlag, Stuttgart, 1965.

6 F. Freese, Thesis, University of Amsterdam, 1971; F. Freese, G. den Boef and G. J. van Rossum, Anal. Chim. Acta, 58 (1972) 429.

$7 \mathrm{H}$. Diehl and J. L. Ellingboe, Anal. Chem., 28 (1956) 882.

8 B. M. Tucker, Analyst (London) 82 (1957) 284. 